\title{
Upaya Meningkatkan Hasil Belajar Operasi Hitung Bilangan Bulat melalui Model Number Head Together berbantuan Papan Bilangan
}

\author{
Satumah \\ SDN Sampangagung II Kecamatan Kutorejo Kabupaten Mojokerto \\ Email: satumahmoxer@gmail.com
}

\begin{tabular}{l} 
Tersedia Online di \\
http://www.jurnal.unublitar.ac.id/ \\
index.php/briliant \\
\hline Sejarah Artikel \\
\hline Diterima pada 31 Maret 2017 \\
Disetuji pada 6 April 2017 \\
Dipublikasikan pada 1 Mei 2017 \\
Hal. 184-189 \\
\hline Kata Kunci: \\
\hline $\begin{array}{l}\text { number head together, papan } \\
\text { bilangan, }\end{array}$ \\
\hline
\end{tabular}

\begin{abstract}
Abstrak: Tujuan dari penelitian adalah untuk meningkatkan hasil belajar siswa dengan menggunakan alat peraga dan metode NHT pada materi operasi bilangan bulat. Jenis penelitian adalah penelitian tindakan kelas dengan subjek penelitiannya adalah siswa kelas IV SDN Sampangagung II tahun pelajaran 2015/2016. Hasil analisis data menyimpulkan bahwa penggunaan alat peraga dapat meningkatkan minat belajar siswa dalam materi pokok operasi bilangan bulat. Hal ini dapat dilihat dari meningkatnya perolehan skor aktivitas siswa dalam pembelajaran. Persentase rata-rata pada siklus I $(66,67 \%)$ meningkat menjadi $(87,5 \%)$ pada siklus II.
\end{abstract}

Dalam menghadapi tantangan era globalisasi saat ini diperlukan sumber daya manusia yang handal dan memiliki pemikiran kritis, sistematis, logis, kreatif, dan memiliki kemauan kerja sama yang efektif. Sumber daya manusia yang memiliki pemikiran seperti yang telah disebutkan, dapat dihasilkan dari lembaga pendidikan. Pendidikan atau education adalah suatu proses transfer falsafah (philosophy) dan sistem nilai (values), pengetahuan (knowledge) dan kemampuan (ability) yang merupakan bagian paling penting dari investasi sumber daya manusia (invesment in human capital) (Mahardika, 2008: 1).

Berbicara tentang dunia pendidikan, tentunya tidak terlepas dari proses belajar mengajar. Dalam proses belajar mengajar, guru harus dapat melibatkan siswa secara aktif dalam proses belajar mengajar, sehingga dapat meningkatkan daya kreatifitas dan berpikir kritis pada diri siswa. Guru haruslah memiliki kemampuan dan wawasan yang luas serta terampil menjelaskan materi dan juga harus dapat membangkitkan motivasi atau gairah belajar siswa sehingga siswa tidak mengalami kesulitan belajar. Dengan bergairahnya belajar, anak didik tidak sukar untuk mencapai tujuan pengajaran karena bukan guru yang memaksakan anak didik untuk mencapai tujuan, tetapi anak didiklah dengan sadar untuk mencapai tujuan (Djamarah, 2002: 4).

Selain itu, kegiatan belajar mengajar sangat ditentukan oleh kerjasama antara guru dan siswa. Guru dituntut untuk mampu menyajikan materi pelajaran dengan optimum. Oleh karena itu diperlukan kreatifitas dan gagasan yang baru untuk mengembangkan cara penyajian materi pelajaran di sekolah. Kreativitas yang dimaksud adalah kemampuan seorang guru dalam memilih metode, pendekatan, dan media yang tepat dalam penyajian materi pelajaran terutama pada mata pelajaran matematika. Dikarenakan matematika dianggap sebagai mata 
pelajaran yang sulit, baik di tingkat dasar, menengah, bahkan sampai perguruan tinggi.

Berdasarkan informasi yang diperoleh peneliti baik dari para siswa maupun dari beberapa dewan guru di SDN Sampangagung II, Mojokerto yang menyatakan masih rendahnya hasil belajar matematika para siswa. Maka untuk meningkatkan hasil belajar matematika para siswa, perlu dilakukan perubahan pembelajaran diantaranya menggunakan number head together berbantuan papan bilangan.

Model pembelajaran kooperatif tipe NHT adalah suatu model pembelajaran yang menekankan pada struktur khusus yang dirancang untuk mempengaruhi pola interaksi siswa pada suatu lingkungan belajar dimana setiap siswa diberi nomor kemudian dibuat suatu kelompok dan guru memanggil nomor tersebut secara acak. Langkah-langkah pembelajaran kooperatif tipe NHT adalah (1) Menyampaikan tujuan dan memotivasi siswa, (3) Menyajikan informasi, (4) Penomoran, (5) Mengajukan pertanyaan atau permasalahan, (6) Berpikir bersama, Menjawab (evaluasi), (7) Memberikan penghargaan

\section{METODE}

Penelitian ini merupakan penelitian tindakan kelas (PTK). PTK merupakan suatu pencermatan terhadap kegiatan belajar berupa sebuah tindakan, yang sengaja dimunculkan dan terjadi di sebuah kelas secara bersama. (Arikunto, dkk, 2010:3). Pelaksanaan PTK dimulai dengan siklus pertama yang terdiri dari empat kegiatan.Kegiatan pada siklus kedua dapat berupa kegiatan yang sama dengan kegiatan sebelumnya apabila ditujukan untuk mengulangi kesuksesan atau untuk meyakinkan/menguatkan hasil. Akan tetapi umumnya kegiatan yang dilakukan pada siklus kedua mempunyai berbagai tambahan perbaikan dari tindakan terdahulu yang tentu saja ditujukan untuk memperbaiki hambatan atau kesulitan dalam siklus pertama. Jika sudah selesai dengan siklus kedua dan guru belum merasa puas, maka dapat melanjutkan dengan siklus ketiga, yang cara dan tahapannya sama dengan siklus sebelumnya.

PTK ini dilaksanakan di SDN Sampangagung II untuk materi pelajaran Matematika. Sebagai subjek dalam penelitian ini adalah para siswa kelas IV tahun pelajaran 2015/2016. Sedangkan waktu penelitian Penelitian ini dilaksanakan pada pertengahan semester genap tahun pelajaran 2015-2016 selama 5 bulan (Februari - Juni) 2016. Subjek penelitian adalah siswa kelas IV SDN Sampangagung II Mojokerto tahun ajaran 2015/2016 dengan jumlah siswa kelas IV sebanyak 18 siswa.

\section{Prosedur Penelitian}

\section{Tahap perencanaan}

Penentuan materi atau pokok bahasan; Menyiapkan sumber belajar; Menyusun perangkat pembelajaran (membuat RPP); Menyusun format evaluasi; Menyusun format observasi; Membuat kunci jawaban

\section{Tahap pelaksanaan}

Pemberian motivasi kepada siswa; Melakukan kegiatan inti. 


\section{Tahap pengamatan}

Selama proses belajar mengajar di kelas, peneliti akan diamati oleh 1 orang pengamat yaitu guru pengajar matematika yang akan mengamati kemampuan guru (peneliti) dalam mengelola pembelajaran, apakah sudah sesuai dengan RPP yang dibuat. Sedangkan aktivitas siswa akan diamati langsung oleh guru yang bertindak sebagai peneliti.

\section{Tahap refleksi}

Kegiatan pada tahap ini antara lain: (1) mengadakan evaluasi pelaksanaan pembelajaran meliputi evaluasi mutu, waktu dari setiap tindakan, (2) melakukan pertemuan untuk membahas hasil evaluasi, (3) memperbaiki pelaksanaan tindakan sesuai hasil evaluasi untuk digunakan pada siklus berikutnya, (4) mengidentifikasi respon siswa pada saat tindakan pembelajaran.

\section{Instrumen Penelitian}

Adapun instrumen yang digunakan dalam penelitian ini adalah: (1) Rencana pelaksanaan pembelajaran (RPP), (2) Lembar observasi PBM, (3) Tes hasil belajar siswa.

\section{Metode Pengumpulan Data}

Adapun metode pengumpulan data yang dipergunakan dalam penelitian ini adalah : Observasi dan Tes.

\section{Teknik Analisis Data}

\section{Teknik analisis aktivitas siswa}

aktivitas siswa dihitung dengan rumus :

$$
P=\frac{t}{l} \times 100 \%
$$

Keterangan :

$P \quad=$ prosentase aktivitas siswa

$t \quad=$ jumlah skor aktivitas yang dilakukan oleh siswa

$l \quad=$ skor ideal

\section{Teknik analisis hasil belajar siswa}

Dalam penenilitian ini, siswa dianggap telah tuntas apabila telah mencapai nilai KKM (Kriteria Kelulusan Minimum) yang telah ditetapkan sekolah yakni skor 65. Sedangkan ketuntasan hasil belajar siswa secara klasikal paling sedikit $85 \%$ siswa tersebut tuntas belajar secara individual.

\section{HASIL}

\section{Diskripsi Siklus I dan Siklus II}

Aktivitas siswa

Skor perolehan aktivitas siswa dapat dilihat pada tabel berikut ini:

Tabel 1. Perolehan Skor Aktivitas Siswa Siklus I

\begin{tabular}{cccc}
\hline Kelompok & Skor perolehan & Skor Ideal & Persentase \\
\hline I & 10 & 16 & $62,5 \%$ \\
II & 10 & 16 & $62,5 \%$ \\
III & 12 & 16 & $75 \%$ \\
\hline
\end{tabular}




\begin{tabular}{llll}
\hline Rata-rata & 10,67 & 16 & $66,67 \%$ \\
\hline
\end{tabular}

Adapun nama anggota dari masing - masing kelompok dapat dilihat pada tabel berikut ini:

Tabel 2. Pembagian Kelompok pada Siklus I

\begin{tabular}{lccc}
\hline No & Kelompok I & Kelompok II & Kelompok III \\
\hline $\mathbf{1}$ & ADDR & MER & MSAKPR \\
$\mathbf{2}$ & ARA & AS & NK \\
$\mathbf{3}$ & AM & CM & NAR \\
$\mathbf{4}$ & FR & DFA & NLR \\
$\mathbf{5}$ & LDM & ITA & RYA \\
$\mathbf{6}$ & MFR & LN & FZ \\
\hline
\end{tabular}

Perolehan skor aktivitas siswa siklus II dapat dilihat pada tabel berikut:

Tabel 3 Perolehan Skor Aktivitas Siswa Pada Siklus II

\begin{tabular}{cccc}
\hline Kelompok & Skor perolehan & Skor Ideal & Persentase \\
\hline I & 13 & 16 & $81.25 \%$ \\
II & 15 & 16 & $93,75 \%$ \\
III & 14 & 16 & $87,5 \%$ \\
Rata-rata & 14 & 16 & $87,5 \%$ \\
\hline
\end{tabular}

\section{Hasil belajar siswa}

Nilai ketuntasan hasil belajar siswa pada siklus I dan siklus II dapat ditunjukkan pada diagram berikut ini:

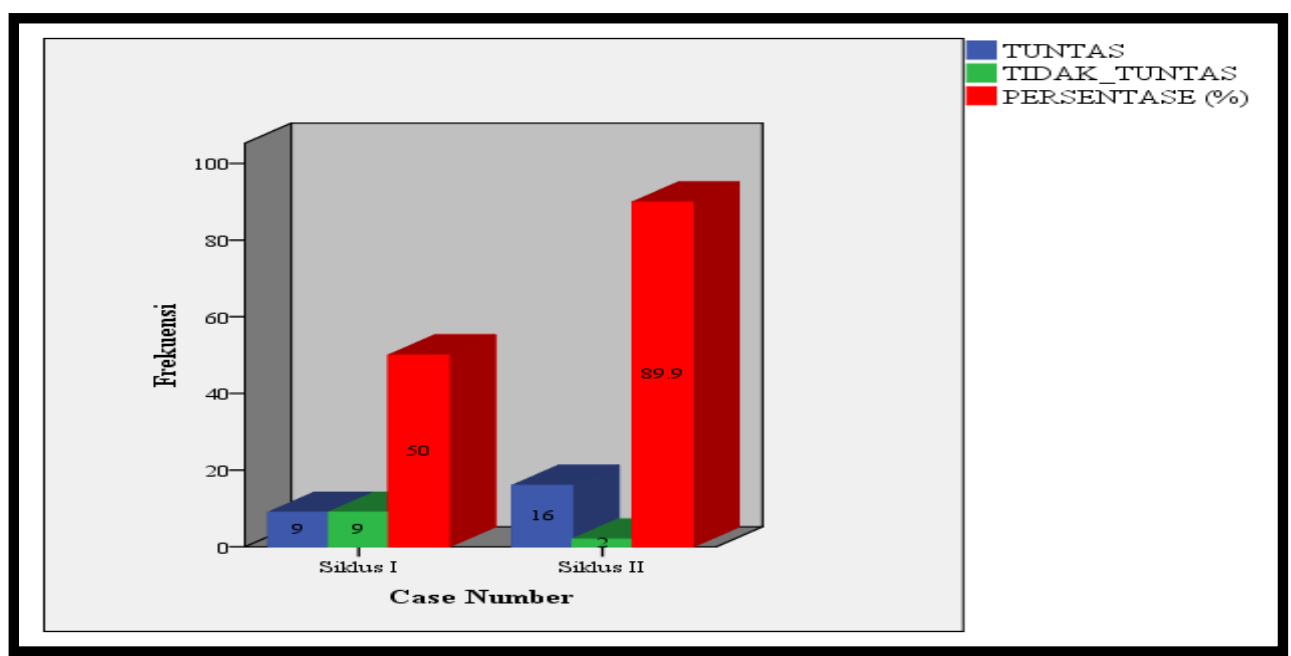

Gambar 1. Diagram Ketuntasan Hasil Belajar Siklus I dan Siklus II

\section{PEMBAHASAN}

\section{Aktivitas Siswa}

Aktivitas siswa pada siklus I belum sesuai dengan harapan yang diinginkan. Hal ini dikarenakan masih ada beberapa siswa yang kurang aktif 
dalam diskusi. Kurangnya aktivitas siswa ini bisa disebabkan karena guru kurang mampu mengelola kelas dengan baik. Guru dianggap kurang mampu mengelola kelas karena ada beberapa siswa yang ramai, bercanda dan mengganggu teman yang lain saat diskusi berlangsung. Selain faktor guru, hal tersebut diatas juga disebabkan siswa kurang bersemangat dalam mengikuti pelajaran.

Dibandingkan dengan siklus I, aktivitas siswa pada siklus II sudah mengalami peningkatan. Keaktifan siswa dalam memperhatikan penjelasan guru, membaca dan mengerjakan pertanyaan, mendiskusikan dan mempersentasikan hasil pekerjaan, serta membuat kesimpulan semakin baik. Selain itu proses kegiatan belajar mengajar lebih menyenangkan. Siswa sudah tidak merasa bosan mengikuti jalannya pelajaran karena ada alat peraga. Selain itu guru juga selalu memberikan motivasi pada siswa untuk lebih aktif dalam pembelajaran.

Berdasarkan pembahasan di atas, dapat dikatakan bahwa penggunaan alat peraga dapat meningkatkan aktivitas siswa kelas IV SDN Sampangagung II dalam mempelajari materi operasi bilangan bulat.

\section{Hasil Belajar Siswa}

Pada siklus I, hasil belajar dari 18 siswa masih belum memuaskan. Hal ini dikarenakan ada 9 siswa yang tidak tuntas belajarnya karena nilainya belum mencapai Kriteria Ketuntasan Minimal (KKM). Sedangkan yang tuntas juga ada 9 siswa. Hal ini berarti pembelajaran belum mencapai ketuntasan klasikal karena persentase ketuntasan pada siklus I ini hanya sebesar $50 \%$. Nilai rata-rata dari hasil belajar siklus I juga hanya mencapai 60,83 . Nilai rata-rata hasil belajar yang tidak begitu tinggi ini dapat disebabkan oleh kurangnya motivasi belajar siswa. Sehingga saat kegiatan pembelajaran berlangsung hanya beberapa siswa yang memperhatikan. Akibatnya saat diberi kuis pada siklus I hasilnya kurang memuaskan.

Hasil belajar pada siklus II mengalami peningkatan yang cukup tinggi, yaitu dari 18 siswa hanya ada 2 siswa yang masih tidak tuntas belajarnya karena nilainya belum mencapai Kriteria Ketuntasan Minimal (KKM). Sedangkan siswa yang tuntas ada 16 siswa yang berarti telah mencapai ketuntasan klasikal sebesar $88,89 \%$. Hal ini berarti terdapat peningkatan sebesar 33,89\% dari persentase pada siklus I. Nilai rata-rata pada hasil belajar siklus II juga dapat dibilang memuaskan yaitu sebesar 78,89. Nilai rata-rata hasil belajar pada siklus II ini mengalami peningkatan 18,06 dari rata-rata pada siklus I yang hanya mencapai 60,83.

Nilai rata-rata kuis yang meningkat pada materi operasi bilangan bulat menunjukkan bahwa pembelajaran menggunakan alat peraga dapat meningkatkan hasil belajar siswa kelas IV SDN Sampangagung II.

\section{KESIMPULAN}

Berdasarkan hasil penelitian dan pembahasan yang telah diuraikan dapat disimpulkan sebagai berikut: (1) Penggunaan alat peraga dapat meningkatkan aktivitas siswa. Hal ini terlihat dari meningkatnya persentase rata-rata perolehan skor aktivitas siswa yang pada siklus I hanya memperoleh $66,67 \%$ meningkat menjadi $87,5 \%$ pada siklus II. (2) Penggunaan alat peraga dapat meningkatkan aktivitas guru dalam mengelola pembelajaran. Hal ini dapat terlihat dari perolehan rata-rata hasil pengamatan kemampuan guru dalam mengellola pembelajaran yang meningkat dari 3,00 pada silkus I menjadi 3,87 pada siklus II. (3) Penggunaan

188 BRILLIANT: Jurnal Riset dan Konseptual Volume 2 Nomor 2, Mei 2017 
alat peraga dapat meningkatkan hasil belajar matematika siswa. Hal ini dapat terlihat pada meningkatnya rata-rata perolehan hasil belajar siswa yang pada siklus I hanya mencapai 60,83 menjadi 78,89 pada siklus II.

\section{SARAN}

Dalam melaksanakan model number head together berbantuan papan bilangan tersebut, hendaknya guru dapat membuat perencanaan yang baik sehingga pembelajaran bisa berjalan dengan efektif dan efisien. Materi dapat tersampaikan dengan waktu yang cukup.

\section{DAFTAR RUJUKAN}

Asyhar, R. 2011. Kreatif Mengembangkan Media Pembelajaran. Jambi: Gaung Persada Press

Djamarah, S.B. dan A. Zain. 2002. Strategi Belajar Mengajar. Jakarta: Rineka Cipta.

Mahardika, I Made S. 2008. Pengantar Evaluasi Pengajaran. Surabaya: Isori Jatim.

Sudjana. 1987. Dasar Proses Belajar Mengajar. Bandung: Sinar Baru Algensindo 